\title{
Reconnoitering Combatant Moral Equality
}

\author{
ROGER WERTHEIMER \\ Philosophy Department, Agnes Scott College, Decatur, GA, USA
}

\begin{abstract}
This essay scouts the conception of combatant moral equality in the preceding papers by Dan Zupan and Jeff McMahan, and especially in the recent interchange between McMahan and Michael Walzer. With McMahan, I deride the idea that aggressor combatants have some moral right to kill, but, unlike him, I deride the idea of such a legal right. I accept only a presumption of blamelessness, and argue that Zupan actually agrees. Combatant moral equality, I argue, has import only for conscientious objection, and (contra McMahan and Walzer) not for our war conventions or just war theory. Walzer is criticized for over-emphasizing our collective responses to war conduct and slighting our personal, extra-political responses.
\end{abstract}

KEY Words: combatant, noncombatant, equal, just war, legal right, punishment, collective, responsibility, blame, conscientious objection

\section{Introduction}

Talk of 'the moral equality of soldiers' entered the language of war ethics with the book that has set the terms for scholarly war ethics debate for decades, Michael Walzer's Just and Unjust Wars (1977). My old officemate, Adm. Hank Chiles, USN (ret), complains that Walzer should have called it 'the moral equality of combatants' since Walzer plainly means to refer just as much to sailors, airmen, and all military personnel at war who may be killed without liability to legal sanctions. Chiles is certainly right about that, even though what exactly Walzer and others mean to refer to is decidedly uncertain.

This essay scouts these uncertainties in the preceding papers by Dan Zupan (this issue: The Logic of Community, Ignorance, and the Presumption of Moral Equality: A Soldier's Story) and Jeff McMahan (this issue: Collectivist Defenses of the Moral Equality of Combatants), and much more in the recent interchange between McMahan (2006a, 2006b) and Walzer (2006). These discussions, especially the latter, are dizzying for readers. Nearly all the crucial premises and practical conclusions are common ground, yet the conceptions of the debate seem starkly disparate. In particular, McMahan insists he is hunting big-game and has bagged the dominant conception of the morality of

Correspondence Address: Roger Wertheimer, Philosophy Department, Agnes Scott College, Decatur, GA 30030, USA. E-mail: rwertheim@juno.com 
war, while Walzer dismisses their differences as 'minor' and perhaps 'only terminological'.

Walzer stipulates that combatant moral equality is the idea or principle that opposing combatants have an 'equal right to kill' each other. McMahan insists on this definition and rightly observes that many discussions do not consistently focus on the principle so specified. He does not note that this threatens his aspiration. If few people really defend McMahan's target (despite what many of them may say), it is not really the dominant war morality, though it may, nonetheless, be worth attacking.

While Walzer asserts and McMahan denies that combatants have an equal moral right to kill each other, they confidently agree that there is an equal legal right to kill here. They don't mean merely that each nation gives its own combatants a duty and thus a right to kill enemy combatants. That right is not recognized by the enemy nation, its allies and neutral nations. Walzer and McMahan have in mind a right recognized by the conventions governing the community of nations. Evidently they infer there is and must be such a right simply because the conventions are silent: the rules don't say there is no such right; the act is not outlawed and made liable to sanctions by the community of nations. Walzer and McMahan seem deaf to the wisdom in the dictum, inter armes silent leges. Talk of rights has entailments Walzer and McMahan don't take seriously. The war conventions don't deny a right to kill, and don't affirm it either.

The conventions do not recognize or protect this 'right' in any way other than their silence in not outlawing it. They do prohibit the punishment of aggressor combatants for killing enemy combatants, because they prohibit the harsh treatment of any captured combatant, period. With so much silence, talk of rights tumbles into paradox. Walzer does not flinch when inferring that if enemy combatants have a right to kill you, then you have lost your right to life as relates to them (1977: 136). Neither Walzer nor McMahan attend to the absurdity that if you have no right to life and someone has a right to kill you, then you can have no right to protect your life and prevent him from killing you: doing so must be illegal. Merely fleeing, let alone fighting back, would be liable to legal sanctions.

McMahan thinks this 'right' to kill is a 'liberty right', a 'legal permission'. A civilian's liberty right to compete for some good operates despite competitors having rights to interfere with each other's exercise of their right to compete, for the varieties of permissible interference are limited. Each combatant's alleged right to kill (maim, imprison) his enemies is supposed to coexist with all of them having an equal unlimited to right to kill (maim, imprison) him to preclude his ever exercising his right - and he has no right to prevent them!

We could as well say that combatants have an equal legal right to kill enemy noncombatants. This is a more limited right. Targeting civilians is punishable. Still, rules of engagement permit combatants to knowingly, albeit unintentionally, kill enemy civilians with impunity. In peacetime, people may with impunity knowingly cause collateral deaths to achieve some good only if that good is a net benefit when everyone's interests - including the victims 
and their community and not just the agents and their allies - are impartially valued. Since jus in bello rules are to be neutral between aggressors and defenders, they cannot require an aggressor to be pursuing some objective good besides satisfying its own interests, for that would preclude the aggressor justifiably inflicting any collateral damage. So, aggressor combatants can with impunity knowingly kill any number of enemy civilians as unavoidable collateral damage in their military campaign to subjugate the remainder of the populace. Perhaps, since a combatant has no right to target a noncombatant, noncombatants do not lose their right to protect themselves by fleeing or reinforcing the target area. They could not protect themselves by fighting back; to target combatants is to be a combatant.

Such absurdities are compounded by the implication that the effect if not intent of the war conventions is to establish that just by attacking another country a nation deprives that country's military personnel of their right to life by bestowing on aggressor combatants a right to kill them at will and to kill enemy civilians as side effects of the war effort.

Talk of legal rights here might be pointful if prohibitions of harsh treatment of war prisoners were meant to legally enforce a moral right to kill. But talk of moral rights here lands in similar absurdities. Yet Walzer declares that this moral right is 'the central principle' of 'the rules of war' (1977: 41), and McMahan here suggests that without it the propriety of the war rules is in jeopardy. This is puzzling in the extreme, since both McMahan and Walzer demonstrate awareness of some of the many obvious moral and prudential reasons justifying our war rules quite apart from any idea of combatant moral equality. Let's briefly review some of the reasoning for current war conventions that readily occurs to reasonable people.

Assume that combatants are morally unequal, that aggressor combatants commit moral wrongs by killing enemy combatants, and that many of them deserve to suffer for it. Still, no one is wronged by their going unpunished. The justice of retribution doesn't oblige us to punish. Besides, deserved it may be, but history offers scant hope of substantial good coming from punishing aggressor combatants. Aggressors have known that defeat meant they'd meet a terrible fate. Expectably, they were undeterred. Unlike most foiled crimes, defeat in war is always costly, often catastrophic, with or without post-bellum penalties, so nations rarely aggress without ample confidence of attacking with impunity. ${ }^{1}$ Further, instead of deterring aggressors, a threat of punishment is a disincentive to surrender, so the threat threatens to aggravate warfare. Then too, abusing captured aggressors tends to encourage rather than discourage abuse of captured defenders. Nations have far more reason to seek protection of their own captured combatants than to abuse captured enemy combatants. So, while some combatants may deserve punishment, all nations mutually benefit from establishing and respecting international prohibitions of abusing captive combatants.

These prohibitions have other compelling justifications that deny or do without combatant moral equality. Recall, by threatening punishment of captives, a nation risks prolonging hostilities and increasing its own casualties. While a nation may justifiably command its citizens to risk limb 
and life defending their nation, it has no entitlement to put their lives in peril simply to punish the injustices of foreigners and quite apart from benefits to the nation. Some people risk their own lives to avenge and vindicate themselves or their beloveds. That may be downright irrational but still understandable. Anyway, it is not unjust, so it is morally miles from compelling citizens to sacrifice limb or life to exact cosmic justice rather than serve the national interest.

Further, punishing aggressor combatants is a bad business because many and perhaps most of them don't deserve it. We accept a sensible presumption of the sort Zupan argues for that exculpates most combatants. We'll discuss this more below. Doubtless the presumption is often defeated. Many aggressor combatants might be fittingly made to suffer - were it not that punishing masses of troops inevitably inflicts much unmerited suffering upon many inculpable individuals. Wrongly punishing squads of the undeserving perpetrates a greater evil than any good done in punishing battalions of the deserving.

The conventions regard captured combatants as noncombatants. Most reasons for protecting these noncombatants apply generally to justify jus in bello principles immunizing other noncombatants. Put aside tendentious suppositions about which civilians have some responsibility for their nation's aggressive war. The stark moral fact is that the pleasure of retaliating against the responsible persons won't wipe away the howling wrong of exterminating the infants and other human beings who had done nothing to call down hellfire upon themselves. The clear innocence of some targets makes a moral difference.

Yet, nothing but confusion, skepticism and cynicism comes from trying to understand the reasonableness of outlawing noncombatant targeting as resting on moral assessments of the potential victims' individual responsibilities. Every nation has a powerful interest in minimizing the risks of war for its own populace and territory. Nations may have interests in killing enemy combatants to achieve their war aims, but they have few if any substantial interests in killing enemy civilians, except as side effects of other pursuits. Each nation reduces the risks to its own well being when all nations agree to limit assaults of enemy civilians. This calculation has no place for suspect assessments of the relative responsibility, innocence or guilt of civilians versus combatants, or defenders versus aggressors.

So, targeting noncombatants is now a war crime, liable to punishment; targeting combatants is not. Neither rule implies that targeting defender combatants is morally permissible or that aggressor combatants are morally faultless. $^{2}$ The core jus in bello principles have no need of notions of combatant moral equality. Further, those notions cannot be premises of jus ad bellum principles since those notions presuppose the principles distinguishing just from unjust wars, and cannot make or mark the distinction.

Further, intranational law has no more need of Walzer's term than international law does. Nations don't penalize their own citizens who obediently served in their unjust wars. Such penalties would trade the taint of 'victor's justice' for the injustice of ex post facto prohibitions. (Punishing 
collaborators with an erstwhile conqueror needn't suffer that infirmity.) Liberalism argues for state policies respecting individual conscience, but no legal system can coherently recognize its subjects' having a general right to disobey or be exempt from a law whenever compliance would compromise their conscience, for that would reduce all legal imperatives to mere advice. No state can well avoid claiming for itself the prerogative of determining the accommodations it makes for conscientious objection to military service or any other legal requirement. The question of when a community may rightly compel its members to risk their lives and kill others is not adjudicated by deliberating over the morality of military service. Congress exempted those objecting to all wars, but not those objecting to a current war for its distinctive injustice. The US Supreme Court (1971) upheld the Congressional decision by finding (with some good reason) that selective $\mathrm{CO}$ deferments could not be administered with sufficient uniformity and fairness. The Catholic Church and other groups encourage their faithful to both refuse service in unjust wars and respect the state's prerogative to deny or limit military deferments. The propriety of the refusal and the respect are both debatable; their compatibility is not.

So, combatant moral equality is not essential, let alone central, for rationalizing our collective, institutional responses to war conduct. Some theorists like Walzer rely on the notion to justify our war rules, but Walzer and McMahan cite no substantial evidence of the notion explaining the establishment and maintenance of our system of collectivized responses to individual war conduct. Walzer's concept is not a plausible primary explanatory element for why so many nations world-wide ratify the conventions and respect them (to some extent). It is too culturally peculiar. Decision makers around the globe, whatever their intellectual and moral heritage, have signed on with less tendentious, and more transcultural, motivations of national self-interest and more universally accepted ethical principles.

Certainly, some ideas reminiscent of combatant moral equality have long been popular. People everywhere are understandably receptive to the idea that, as long as they follow their leader, the blood they help shed in uniform will not stain themselves. What could be more comforting than a conviction relieving you of any anxieties about your culpability for complicity in killing in a morally dubious enterprise? Certainly political and military leaders tend to encourage that belief since they want their subordinates to follow their commands.

Yet good Christian rulers aren't satisfied with that. In Henry $V$, Shakespeare has his ideal Christian king declaring the traditional Christian conviction that a combatant's conscience can be content only if his leader's cause is just and honorable. Shakespeare then has a fifteenth-century common foot soldier scoffingly say that his kind have no need to know the justice of their leaders' military ventures. Why? The rationalization Shakespeare evokes may be especially popular among combatants of most cultures, but it's a rationale with which many people everywhere run their whole life: The authority is in charge. I'm doing what I'm told. That rationale defines a 
whole structure of thought and attitude Lawrence Kohlberg (1983) calls conventional thought, an intermediate stage of psychological development.

We don't need the controversial elements of Kohlberg's developmental theory to recognize that conventional thought is typical of the grunts of human history. Thoughts like combatant moral equality are common - in more than one sense. What surprises here is that both McMahan and Walzer quote Shakespeare as though the soldier, not the king, occupied the moral center of the play.

Walzer doesn't mean to make apologies for a developmentally arrested moral perspective. He intends to defend a valid moral principle, a norm that everyone has reason for everyone to accept and to apply to everyone - not just to themselves and their comrades, but equally to enemy combatants. The combatant moral equality McMahan targets means that our enemy combatants are our moral equals as fellow human beings, and we all remain equally blameless whatever the righteousness of the causes we serve, and thus equally deserving of decent treatment when we are captured, disabled, and no longer a threat.

McMahan (2006c) baldly declares that combatant moral equality 'has been the dominant view about participation in an unjust war throughout history. Certainly it's the dominant view today'. The historical and anthropological reports I read say otherwise. They say that in much of history wounded enemy combatants have been left to writhe and rot, while their healthy captured comrades have been routinely tortured, conscripted, enslaved or summarily slaughtered. Most commonly the brutality came with no compunctions, and most often with no conception that the enemy combatants had wronged anyone. The maltreatment bespoke enmity, scorn and cold disregard, not resentment or indignation. It was more like killing or caging animal prey than retribution. No notion of combatant moral equality operates in that ethos. That notion assumes some conception of foreign relations governed by universal justice, a conception alien or attenuated in most societies, since most have had a tribalist (nationalist, racist) ethos which extends justice and compassion primarily to compatriots, and secondarily, if at all, only to the neighboring family of communities. Just War Theory long thrived in that ethos. That theory is said to start with Ambrose, Augustine's teacher, a fan of slaughtering heathens without quarter. Throughout medieval times, chivalry constrained relations between noblemen of certain Christian communities. It took centuries for minimal courtesies to be gradually extended to heathen, pagans, and barbarians, Indians east and west, and Irish north and south. Combatant moral equality cannot be recognized before recognizing foreigners as moral equals.

Nor can combatant moral equality be recognized before recognizing the riff-raff in the ranks as an officer's moral equal. Chivalry required respect for fellow nobility, and thus gentle treatment of enemy officers, but not much of either for an officer's own cannon fodder, and less still for faceless enemy troops.

Again, brutalizing enemy combatants has often been hardly a moral concern at all, like brutalizing animals. Other times it has been motivated by 
moral ideas as vengeance for an insult (e.g., an injury) or retribution for an alleged wrong. Either way the brutality mocks all thought of foes as inculpable holders of a right to kill.

Most recently, the politically influential argument for America's maintaining the conventions against torturing enemy fighters was strictly selfinterested: a fear for the plight of captive American troops and a fear for our reputation within the community of nations. The moral majority George W. Bush and Rush Limbaugh command will not be constrained by appeals of impersonal justice and humanitarianism. In their minds doers of dastardly terrorist deeds are fair game; we can righteously work our will on them ungloved. To persuade our self-righteous populace to retain established restraints, Colin Powell, Senators McCain, Graham, Warner and the rest wisely played to the crowd and stayed on message appealing simply to our own long term interests. Depressingly, the senators appear to have been insufficiently persuaded by their own rhetoric and willing to compromise on most everything but the appearances.

Walzer did not find the centrality of combatant moral equality to our war rules by sifting historical data. Rather, he made it central to his own collectivist conception of war morality. Then McMahan made Walzer's collectivist conception central to his own conception of just war theory, the war conventions, and common moral thought.

Walzer (2006) concedes McMahan's account of our assessments of individual responsibility in peacetime, but denies its relevance in wartime. Walzer insists that war essentially and coercively collectivizes our assessments of responsibility: 'it makes the kind of attention we would like to pay to each person's moral standing impossible'. Walzer conception is, I believe, a caricature contrary to the aspiration of modern military professionalism to maintain attention to individual responsibility and moral standing despite or because of all the collectivized activity of the military.

Walzer unwittingly exposes the distortions in his own conception with his perceptive closing criticism of McMahan. McMahan claims to be explaining 'the deep morality of war', and therewith criticizing combatant moral equality. Walzer thinks 'that McMahan's "deep morality" is simply our ordinary morality, and the war conventions represent the adaptation of this morality to the circumstances of war' (2006: 45). Walzer is essentially right about that. McMahan's arguments from his 'deep morality' are persuasive only because and insofar as their moral assessments jibe with intuitions of 'ordinary morality'. But Walzer is myopic about the adaptation of morality to war conditions. He is overly impressed by the way the modern world's collective response to combat collectivizes responsibility for aggression and refrains from holding individual combatants responsible. He proceeds as though the collective response - our war conventions - were morality's last and only word on the matter.

Walzer challenges McMahan to present realistic war scenarios where his individualist assessments of responsibility have substantial application. $\mathrm{He}$ faults McMahan's hypotheticals for their unrealistic assumptions about the kinds of knowledge and viable military options available in actual combat 
conditions. Walzer's complaint has some legitimacy, but it misplaces the real import of McMahan's hypothetical cases. Actually, the most that McMahan's stories exhibit is that strict application of our war conventions would not yield perfectly just results in some situations. Sometimes bending or breaking the rules may be justifiable, if it can go undetected. This condition is a notorious liability of any rules with significant moral consequences, so it is no criticism of any specific rule. McMahan only illustrates the possibility of regrettable consequences of the rules. Walzer rests content that McMahan provides no reasons for revising the rules, and does not appreciate that our recognizing the possible consequent injustices and regarding them as regrettable demonstrate that we can and do make individualized assessments of responsibility in war.

We have good reasons for not criminalizing aggressor combatant conduct, and for not criminalizing adultery. That the reasons may be matters of mutual benefit does not mean they are merely 'pragmatic reasons' as McMahan calls them and not also morally compelling reasons. They don't imply that all is fair in love and war.

Combatants often feel driven to individualized assessments of culpability in war conduct - and doubts of combatant moral equality - when they reflect on their current or past contribution to an unjust war with feelings of guilt, remorse, shame or the like. Potential combatants anxious about their liability to self-loathing agonize over individualized, personalized evaluations of combat responsibilities. We civilians exhibit the same intellectual capacities and moral dispositions when we share the combatants' judgment of the wrongs they have done, and respect their feelings as rational, reasonable, not inappropriate, and when we express our respect in our social and political relations.

The real, great import of belief in combatant moral equality has never been in our laws and conventions, international or national. Nor, pace McMahan, is it 'central to the theory of just war in its currently orthodox form' (2006c) or the 'traditional' theory (2006a). Notwithstanding the influence of Walzer's book where combatant moral equality is made central, if any just war theory has title to orthodoxy and tradition, it is that of Catholicism where combatant moral equality has been heterodox. The question for Augustine and Vitoria, whom McMahan references, was how a Christian conscience could be clean while killing in an unrighteous cause; their concern is sin and blamelessness, not a legislatable right to kill unjustly.

Combatant moral equality matters in our personal attitudes to ourselves and to each other. Thoughts about it have had their home in thoughts of conscientious objection to military service. They add something further to all the usual reasons for obeying the law and refraining from civil disobedience. Combatant moral equality means that conscience can have no grounds for disobedience here. It says that your victims' blood will not be on your hands; you are automatically absolved of responsibility for the suffering you cause. The credence given that thought has shaped the life-shaping decisions and sense of self of many combatants and potential inductees - and it has fixed 
other people's personal attitudes and social practices regarding the combatants.

Unlike McMahan and Walzer, Col. Zupan gives us a combatant's personal perspective. Combatant moral equality is not a military regulation or official doctrine he is obliged to salute. It, or something like it, has some respectability in his community's ethos, and he has long assumed it, or something like it, but he has his doubts. His paper may somewhat misstate his personal history. My sense of this soldier whom I am honored to consider a friend is that he has long been disposed to say what he is now trying to articulate, and that he misspeaks when he calls it a presumption of combatant moral equality.

A presumption of combatant moral equality is or entails a presumptive moral right of aggressors to kill enemy combatants. A presumptive right is no more a right than presumptive innocence is innocence. The presumption is a cognitive state; it doesn't affect the reality. You may be found guilty, and if found innocent, that means only that the state's cognitive stance requires it to treat you as an innocent; the finding cannot erase real guilt and make you actually innocent. Morally, if the presumption of a right is defeated, the right never existed. Zupan rightly thinks that if (or since) Nazi SS knew - or could and should have known - they were agents of evil, then they had no right to act as they did.

Zupan argues that, until confronted with compelling contrary evidence, a combatant may rightfully presume that he has a duty and right to obey and contribute to harming the enemy, and that enemy combatants may rightfully presume the same of themselves. The presumption is predicated on an insufficiency of justified certainty of (i) the combatant's committing a wrong, and (ii) enemy combatants having obtained enough evidence that they were committing a wrong. That insufficiency seems powerless to entitle anyone to something more than an exemption from blame. Being rightly certain that you are acting wrongly may make you blamable by your loss of an excuse combatants rightly presume to have; it does not make you guilty, some kind of murderer, by depriving you of a right to be complicit in a howling injustice.

If I read him aright, Zupan believes in a presumptive equality of inculpability and blamelessness, not a presumptive moral right of aggressors to kill. In law, this is no mere presumption; in effect, our conventions recognize the uniform as the excuse. Morally, really, it is only a strong presumption of an excuse. While it may remain unrebuttable from lack of sufficient evidence, a combatant in fact had no excuse if in fact he knew or should have known he was acting wrongly.

I don't know how many officers would agree with Zupan's sophisticated principle, but my experience is that more have more sympathy with Zupan than Walzer and McMahan suppose. Zupan's principle is more subtle and nuanced than what theorists attribute to most people and most combatants, but it is more reasonable, and more like the mature moral thinking one expects in a senior officer.

I also suspect that Zupan and many fellows are sympathetic to other sources of the presumption than Zupan discusses. Zupan's focus is that 
citizens have a reasonable presumption that they should obey their legitimate ruler. That general presumption is strengthened by the sacred oaths and special obligations of military personnel. It needs no inane notion of 'invincible ignorance' of the real truth about their war's righteousness. (It is patently impossible for it to be absolutely impossible for combatants to know of their leaders' dishonorable or dubious motives.) Suffice that the presumption of ignorance be substantial albeit rebuttable. Nor need there be any specious supposition that the presumption favoring obedience overrides the presumption against killing because disobedience is intrinsically a greater wrong than homicide. Instead, it's that the presumption favoring obedience functions as a second level principle to presume that the ruler is better positioned to judge whether a first order prescription is overridden by the injustice of the act commanded.

The presumption favoring obedience is buttressed by coincident presumptions of various loyalties - to the nation, to the corps, and, not least, to one's own mates and comrades. Bonds befall us by birth, history and circumstance. Our life and spirit may become so enmeshed with our nation, corps and comrades that we can barely conceive of our having a life or heart or mind detached from theirs. The idea of abandoning them all, betraying them, condemning them is alien and unthinkable - like witnessing your spouse shoplift diamonds and reporting it to the police. It is just not going to happen. And no community expects it.

Loyalties and allegiances are forms of favoritism and partiality that may motivate complicity in injustice. Virtues and principles commonly collide and compete. Loyalty can ally us to iniquity. We may all blandly concede that justice trumps loyalty when the injustice is egregious enough. Yet one test of loyalty to an individual or group is a tolerance of its moral imperfections, a willingness to live with some injustices, to forgive some, and to resist being party to condemning them. The military's intense demand for intense loyalties engenders no end of occasions within the military of loyalty clashing with justice and impersonal authority. That collision has high stakes when the loyalty is to the supreme sovereign authority and the injustice is the infliction of the greatest evils.

Loyalty can look like an abandonment of a chunk of moral autonomy. It may be an attenuation of autonomy or an alternative kind of autonomy or an alternative to autonomy. No one really knows. Notwithstanding their fondest assumptions, ethical theorists don't know whether a human life is badly lived when big parts of it are surrendered to another person or group of persons. Liberal theorists may declare your life debased and your dignity diminished by willingly or unthinkingly yielding some control or the right to control your whole life. But you may declare it an individualist fantasy that a person does or should belong to himself and himself alone. You may instead insist that a human life without particular loves and loyalties is an empty abstraction, nothing to be proud of, and that true love and loyalty require us to stand with the people we're bonded to, even when that means abetting their wrongdoing, and that while some wrongs are too horrific to be tolerated, when the loyalty 
is to our entire community and our community is a colossus, we're liable to find ourselves yoked to colossal wrongs.

Just how much complicity in injustice any loyalty can decently demand is bound to be controversial, and unlikely to be usefully specifiable in general terms. I won't here try. Suffice to recognize that loyalties provide separate presumptions. After we rebut the presumption that the ruler knows better the justice of his commands, after justice silences the call of duty, the presumptions of loyalty might still favor going along.

The twin presumptions of legal duty and loyalty are further buttressed by the presumptions of prudence and rational self-interest. When the first two run out, the latter may be protection enough. The risks and costs of disobedience and disloyalty in combat can be as steep and certain as summary execution. Elsewhere, while your life is not itself on the line, the costs are likely to include, atop a few years of jail time, a lifetime of humiliation and ostracism by family, friends, and fellow citizens. Sure, sometimes keeping one's hands clean may require heroism, and be required nonetheless. Weakness may be no excuse. Yet it may deserve more pity than punishment or righteous condemnation.

Zupan and most people would also, I think, regard McMahan's minimizing the strength of the presumptions unnecessary and unwise. Just cleansing our minds of fantasies of combatant moral equality has significance aplenty. However strong the presumptions favoring fighting, legitimate doubt can no longer be ruled out. Nagging worries become respectable, worthy of a fair hearing. There's no need for implausible exaggerations, for claiming as McMahan (2006c) does, that 'it's seldom reasonable' for unjust combatants to believe their cause is just. That is a jaw-dropping discounting of the cognitive limitations and the weight of the loyalties of the average citizen, in and out of uniform.

Besides, as things stand, the concrete implications of McMahan's calculations stay obscure. Conspicuously absent in his writings are his moral judgments about the propriety or necessity of conscientious objection in specific historical instances. He remains infuriatingly unforthcoming on the hot-button issues whether American troops in Vietnam are condemnable for failing to lay down their arms, and whether our soldiers in Iraq are morally culpable for not resigning individually or en masse. Whatever be his own historical understanding, I suspect many people would infer from the principles he outlines here that Americans should have refused military service in WWI and WWII and Iraq I. Until he bites such bitter bullets, the practical import of his proposals could be small potatoes or something large and indigestible.

McMahan should be well pleased with his work if it serves only to deflate Walzer's influence. Their debate is no mere ivory-tower scholarly quarrel. Walzer's book is having massive influence (albeit less than McMahan imagines), not least by being the sole text on its topic now required reading in most American war colleges and all the required ethics courses of the American academies educating and commissioning army, air force, navy and marine officers. As things are, talk of combatant moral equality gets far too 
much respect in our military. On the one hand, there is a commendable (if not universal and consistent) tendency to raise cadet and midshipman consciousness of the moral fact that ultimately we all act at our moral peril. They are occasionally informed that there's no exit, short of death or lobotomy, from moral responsibility for their own deliberate conduct. Their corps and country can absolve them only of legal, not ethical, accountability. They hear that message, occasionally. But they are not much confronted with the awful conflict between that message and Walzer's. My general impression (or wishful thinking) is that the endorsements of combatant moral equality are lip service to something not well understood, and that Zupan better expresses the military ethos than Walzer.

Myself, I'd feel amply rewarded if I moved Walzer to revise the next edition of his seminal work and erase all traces of combatant moral equality. I fervently hope he'll heave-ho this excess baggage, loaded with paradox and implausibility. Deobfuscated it says your ruler disappears your right to life by dressing you in khaki, and exchanges that right for a right to kill anyone another government has put in uniform! $!^{3}$ That idea is loony. Why resort to black box bureaucratic morality when the reasonableness of our war rules is evident without it?

Hitching oneself to this hokum is catastrophic in the one place it really impacts. The greatest disappointment of Just and Unjust Wars comes when it gets round to conscientious objection. There, as throughout, the book's great deficiency is its viewing its subject solely from the perspective of an outside observer, a political theorist, and never sensitively from the perspective of actual and potential participants. A brief section at book's end starts confronting individual responsibility where it matters, not geo-politically, but personally, emotionally, existentially. Yet it sees everything through a political prism. The section is entitled 'Democratic Responsibilities', not 'Personal Responsibilities'.

The crux of Walzer's teaching on conscientious objection is confined to a footnote filled with rhetorical flourish (1977: 299-300). He rightly asks us to honor those Americans who refused to fight Vietnam. Honest patriots ask: Where is the honor in refusing to do what is not the least dishonorable? If our Vietnam vets did nothing wrong killing according to the rules of engagement, how could their CO peers righteously refuse when their nation called? Walzer never honestly confronts that whopping worry. Instead, while commending refusal, Walzer confidently assures us that those who fight cannot be called criminals. That is a heartlessly unhelpful observation when everyone knows that the only crime to commit here is the refusal to fight. A combatant's anxiety about pulling the trigger has nothing to do with law and crime, but with sin or its secular counterpart. His troubled conscience won't be stilled by Walzer's casuistically splitting a combatant's soul, holding him morally responsible as a citizen and absolving him of such accountability as a member of a military collective. The cruel fact is that conscience doesn't work that way. The citizens who supported a war they later condemn never suffer near the agonized guilt and shame of their warriors who see and touch and smell the flesh they rend and roast. 
The great theme of Walzer's book is war's collectivizing responsibility. Yet, when he gets to conscientious objection, he says: 'Though responsibility is always personal and particular, moral life is always collective in character' (1977: 298). How he reconciles that sentence's first clause with his general thesis is opaque to me. The second clause seems to mean something more specific than a philosophical platitude about universalization and generalization in ethics, something that dismisses the specifically personal and interpersonal dimensions of morality distinct from the political. Walzer accepts the plausible standard for individual accountability for communal acts J. Glenn Gray proposed, and he rightly recoils against Gray's exaggerated, romanticized individualism that thinks 'we can never apply [the standard] to anyone but ourselves' $(1977,298)$. Walzer goes to the other extreme, or two other extremes, for he insists on both the impossibility of applying the standard to combatants, and the necessity of applying it to all citizens. He declares that Gray's 'kind of self-regard is not possible in politics and morality. Judging ourselves, we necessarily judge other people, with whom we share a common life' (1977: 298). That may be true of politics and public life, but Zupan seems to feel about some situations, and specifically about conscientious objectors something many people express with words like: I cannot help judging my own choices and conduct, but whether, when and where I can rightly presume to judge other people's conduct in the matter are delicate moral questions. The answers impact my personal attitudes towards the people and my personal relationships with them. The significance of those consequences may tend to justify a presumption not to judge.

Our future officers have an existential need to study a more nuanced analysis of their moral plight, preferably stated with enviable Walzerian eloquence. They need to appreciate that this matter is no mere classroom Gedanken-experiment, but rather the all too real-world possibility that they may find themselves commanded to be complicitous in inexcusable, shameful bloodshed, and that their conscience can't be clean without a good faith effort, undertaken with due humility, to weigh their conflicting responsibilities.

I don't presume to judge the decisions they would then make. This whole matter has troubled my conscience and philosophical convictions for near forty years now, since I sat on a bus heading for an Army induction center. There I was, 26, a philosophy graduate student, with a wife and child and a draft deferment revoked for returning my draft card in protest of the Vietnam war - but fortified with a fair shot at a medical deferment and a firm resolve to refuse if need be. My fellow passengers were visibly anxious, semi-educated 18-year-olds, luckless losers in the draft lottery. I sat paralytically mulling fantasies of moral heroism, of standing up and speaking out and in fifteen minutes of earnest, analytically acute eloquence stirring my fellow man to revolt. I stayed silent, muffled by the depressing reality that I'd likely be shouted down or dismissed, doing nothing but mercilessly aggravating my bug-eyed bus-mates' turmoil.

I have always cheered and admired my countrymen who courageously and conscientiously resisted the draft, or resigned their commissions, or went 
AWOL. But blaming all those who couldn't or didn't keep their hands clean has seemed to me the height of self-righteousness. This has been for me the paradigm case of feeling forced to make that paradoxical admission: 'It is not for me to judge them'.

Soon after escaping induction I entered law enforcement, surrounded at the police academy by returning vets, 21-23 years old, some there by dint of a veterans preference employment policy. I know many of my academy peers judged themselves and lived with their self-lacerations. My heart has gone out to them, my peers, nearly my age, precisely because I could not console them with reassurances that they had not in fact done anything wrong. They had. But adding my condemnation to their self-condemnation smacked of selfindulgent moralistic cruelty.

Yet I also haven't blamed all who came away untraumatized, their conscience intact, untroubled by nagging doubts about their honor. As the war dragged on and the grimness of its inception, progress and prognosis became more evident, I felt challenged to excuse anyone who just didn't get it that this war had to stop, immediately, that no amount of American prestige could excuse the decimation of another peasant village. Yet I still sense I must excuse them, somehow, and I do, somehow. I tolerate their epistemic eccentricity much as I tolerate the delusions of devout Baptists and Catholics and Muslims and Hasidim who believe things that seem to me beyond all reasonable credence. I've known personally many such people whom I could not but respect despite their unreasonable understanding of the world. I don't presume there must be something wrong with someone who sees the world that way, that there's something shameful in living a human life this way, with these convictions, and perceptions, and preferences.

There can be. The many American troops who reviled the Vietnamese merit only the most minimal, if any, respect. Some may have managed to avoid anything illegal, but they had few compunctions about killing innocent peasants as well as Viet Cong. And my feelings of tolerance have been tested by those God-fearing super-patriots innocent of racial and ethnic bigotry who have still today never known a twinge or qualm about the horror we rained on Vietnam. It's very different when their patriotism hasn't suffocated their sense of decency, and they are able to honestly confront what we wrought, acknowledge the tragedy and sincerely regret that they had to contribute to it, but nonetheless remain confident that they fought honorably in an honorable cause.

Forty years of reflection has sharpened my certainty that there was no honorable cause, and that nonetheless some Americans fought honorably, and that the grand abstractions of ethical theory lack the candlepower to cut through all the thick murk of such moral dilemmas and provide our military personnel clear and specific guidance. 


\section{Acknowledgements}

My thanks, per usual, to Bredo Johnsen and Lara Denis for numerous helpful suggestions.

\section{Notes}

${ }^{1}$ Certainly, many aggressor combatants have been undeterrable conscripts or clueless dupes or the like. Still, many aggressor combatants have been plenty knowledgeable and willing. The flip side of this is that the modern decent treatment of captured aggressor combatants has not increased the incidence of warring.

${ }^{2}$ If anything, combatant moral equality collides with privileging noncombatants. Defensive combatants may have done nothing more than a civilian that would entitle the enemy to kill them. If aggressor combatants were really the defenders' equals in righteousness, then they too could not be rightfully killed. Combatant moral equality would imply that everyone, aggressor and defender, combatant and noncombatant, all alike should be equally proper or equally improper targets - were it not that the idea is implicitly self-contradictory so it implies everything and nothing.

${ }^{3}$ Walzer's defenses of combatant moral equality never close the great gap between his characterization of combatants and the war conventions' criteria. Walzer's justification runs in terms of 'those who do the fighting'. The conventions specify the uniformed personnel of a nation's military (excepting those with special insignias like the medical corps). In Vietnam only around 15\% of American uniformed personnel were combat troops, those directly engaged in fighting. More significant than the sheer small percentage is that the choices whether tasks somehow supporting the fighters are performed in military uniforms or outsourced to civilians are administrative decisions made on grounds of cost-effectiveness, military traditions, bureaucratic rules, and political expedience. The reasons have tenuous relations to the morally compelling reasons for our war conventions imposing conventions of dress and appearance to distinguish combatants.

\section{References}

Kohlberg, L., Levine, C. \& Hewer, A. (1983) Moral Stages: A Current Formulation and a Response to Critics (New York: Karger).

McMahan, J. (2004) The ethics of killing in war, Ethics, 114, pp. 693-733.

McMahan, J. (2006a) The ethics of killing in war, Philosophia, 34, pp. 23-41.

McMahan, J. (2006b) Killing in war: A reply to Walzer, Philosophia, 34, pp. 47-51.

McMahan, J. (2006c) Uehiro Lectures, Oxford University.

U.S. Supreme Court (1971) Gillette v. U.S. (401 U.S. 437)

Walzer, M. (1977) Just and Unjust Wars (New York: Basic Books).

Walzer, M. (2006) Response to McMahan's paper, Philosophia, 34, pp. 43-45.

\section{Biography}

Roger Wertheimer received Harvard's Carrier Prize (outstanding philosophy doctoral dissertation) and a Guggenheim Fellowship, taught at numerous universities across the USA, worked as a Deputy Sheriff, psychotherapist, and entrepreneur, published widely in applied ethics, ethical theory, and philosophy of language, and served as the Distinguished Chair in Ethics at the US Naval Academy (2001-2003). Currently he is finishing a book, Empowering Our Military Conscience: Transforming Military Moral Education and Just War Theory. 
Copyright of Journal of Military Ethics is the property of Routledge and its content may not be copied or emailed to multiple sites or posted to a listserv without the copyright holder's express written permission. However, users may print, download, or email articles for individual use. 